\title{
Disposal of Municipal Solid Waste by Bio Methanation in Sangli City
}

\author{
Mohasinkhan N Bargir*, Rohit R Deshmukh, Tejas S Kokitkar, Harshad J Sanghwardhan, Abhishek V \\ Tashildar and Nupur P Kulkarni
}

Department of Civil Engineering, Shivaji University, SBGI Miraj, India

Received 10 Sept 2018, Accepted 12 Nov 2018, Available online 14 Nov, Vol.8, No.6 (Nov/Dec 2018)

\begin{abstract}
India is developing country where population increases per year. As time progressed the peoples are migrated from towns to cities, they generate more and more MSW. Nowadays in India, the most common ways of handling waste are to open dumping and uncontrolled burning. These methods are causing severe environmental pollution and health problem. However, there are some other effective methods are present in nowadays to reduce the amount of waste generated such as Bio methanation. Today in sangli city the collected waste is sent to the landfill site without doing any process on it. Hence it is necessary to design solid waste treatment facility to the sangli city. In this paper and attempt is made to design biomethane plant for disposing of waste generated in sangli city which provides number of other benefits in the form of methane gas which could be used for cooking, electricity generation and manure for farming. The study concluded that the installation of biomethane plant in sangli city for disposing of MSW is improving solid waste management practice so as to reduce environment pollution, saving transportation cost of waste and improve quality of life in city.
\end{abstract}

Keywords: Solid waste management, population forecasting, generation rate, Biomethane plant, Design.

\section{Introduction}

The problem of waste generation and management is becoming a one of the intractable environmental problem in developing cities in India. As the time progressed the peoples are migrated from town to cities, they generated more and more waste. The material which is arises from various human activities and which is normally discarded as useless or unwanted it is known as solid waste. The solid waste are various types; generally, it is categorized as municipal waste, industrial waste, hazardous waste. Municipal solid waste(MSW) are the waste which is generated from market, domestic waste, vegetables waste etc.

Today in Sangli city daily collection of the solid waste is $210 \mathrm{MT} /$ day in 2016 which will go up to 435 $\mathrm{MT} /$ day in 2046. It was necessary to address this problem systematically by going in all aspect of solid waste management (SWM) and device a simple but cost-effective system. Nowadays the rate at which the waste is being generated is about $70 \%$ as compared to total rate of its disposal which is $30 \%$. Municipal Corporation of the city of sangli has therefore initiated

*Corresponding author Mohasinkhan N Bargir (ORCID ID:00000002-3959-5924), Rohit R Deshmukh, Tejas S Kokitkar, Harshad J Sanghwazrdhan, Abhishek V Tashildar are UG Students; Nupur P Kulkarni is working as Assistant Professor DOI: https://doi.org/10.14741/ijcet/v.8.6.9 the action for upgrading all its MSW management system in line with this concept to achieve the results envisaged under the rules 2000. The different types of municipal solid waste (MSW) is given in Table- 1 .

Table-1 Different types of MSW

\begin{tabular}{|c|c|}
\hline Residential & $\begin{array}{l}\text { Food waste, food container, can, bottles, } \\
\text { paper, newspaper, cloth, garden waste, } \\
\text { furniture waste. }\end{array}$ \\
\hline $\begin{array}{l}\text { Commercial } \\
\text { Centre }\end{array}$ & $\begin{array}{l}\text { Vary types of papers and boxes, food waste, } \\
\text { food container, chair, tables waste, packaging } \\
\text { material. }\end{array}$ \\
\hline $\begin{array}{c}\text { Institutional } \\
\text { Waste }\end{array}$ & $\begin{array}{l}\text { Office waste, broken benches, garden waste, } \\
\text { furniture waste }\end{array}$ \\
\hline $\begin{array}{l}\text { Industrial } \\
\text { waste }\end{array}$ & $\begin{array}{l}\text { Housekeeping waste, packaging, food waste, } \\
\text { construction and demolition waste, } \\
\text { hazardous waste, special waste. }\end{array}$ \\
\hline
\end{tabular}

\subsection{Functional Element of MSW}

The growth in MSW (municipal solid waste) generation in India has outpaces the growth in population in the recent years. The daily per capita generation of municipal solid waste in India ranges from about $100 \mathrm{~g}$ in small town to $500 \mathrm{~g}$ in large towns. The recyclable content of waste in India ranges from about 13\% to $20 \%$. The survey conducted by CPCB puts total municipal waste generation from class I and II cities to around 18 million tons in 1997. The reason for this 
escalating trend is a mix of the changing lifestyle, food habits and changes in standard of living.

\subsection{Waste Management}

Management of solid waste may be defined as that discipline associated with the control of generation, storage, transfer and transport, processing and disposal of solid waste in a manner that is accord with the principles of public health, economies, engineering, conservation, aesthetic, and other environmental considerations in its scope. Waste management is the methodology used to achieve waste reduction, primarily through education at source, but also including recycling and reuse of materials, as shown in the fig. 1.1 below.

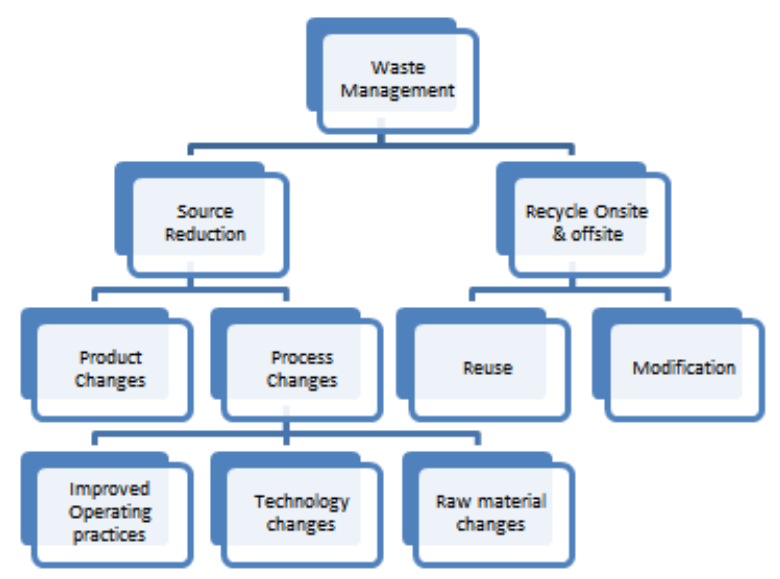

Fig-1 Waste Management

\subsection{What is meant by Bio-methanation?}

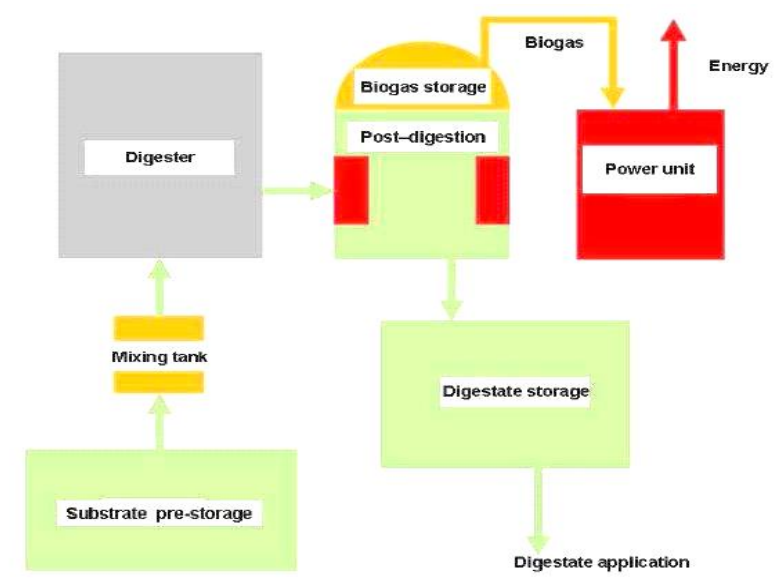

Fig-2 Bio methanation Process

Bio methanation is a process by which organic material in the waste is microbiologically converted under anaerobic conditions to produce biogas. Biogas can be produced from raw materials such as agricultural waste, manure, municipal waste, plant Materials, sewage, green waste or food waste. Biogas is a renewable energy source and, in many cases, exerts a very small carbon footprint. This energy release allows biogas to be used as a fuel; it can be used for any heating purpose, such as cooking. It can also be used in a gas engine to convert the energy in the gas into electricity and heat.

\section{Literature Review}

M. K. Stenstrom et.al (1983: In this paper author carryout study to determine the suitability of anaerobic digestion to Los Angeles area wastes, a twoyear pilot - scale study was conducted. A survey of southern California community was made to determine typical MSW composition. Municipal Solid waste with characteristics confirming to survey results was classified using the Cal Recovery process to provide a feedstock for digestion. Four $0.19 \mathrm{M}^{3}$ digester were operated at organic loading rates from $1.04 \mathrm{~kg} / \mathrm{M}^{3}$. day. Feed concentration ranged from $2.6 \%-8 \%$ Vs and hydraulic retention time ranged from 15-30 days. Feed. Feed solid were composed of $80 \%$ classified municipal solid waste and $20 \%$ primary sludge. Results of experimental investigation showed that gas containing $55 \%-60 \%$ methane can be produced at a rate of 0.44 $\mathrm{m}^{3}-0.55 \mathrm{~m}^{3} / \mathrm{Kg}$ applied. The highest gas production rate was obtained at the lowest digester loading rates.

T. Narayana et.al (2008): The author studied MSW system in India, it was found that the solid waste of Asian cities compromised of 70-80 \% of organic matter, dust, dirt. They also studied in several developing country establishing large scale composting plant that eventually failed due to various reason, Landfills have also been widely unsuccessful in country because of landfill site very limited frame of usage. The objective of this study is thus to compare the methods of disposal of MSW, keeping in mind the cost that would be incurred by the respective government, and identify the most economical and best option possible to combat the waste disposal. Based on the result the author concluded that composting after segregation is best possible option to address solid waste in developing country.

A. Shekdar et.al (2009): In this paper, author analyze the situation in different Asian countries and explore future trends. It also conceptually evaluates issue surrounding the sustainability of SWM and propose a multi-pronged integrated approach for improvement that achieves sustainable SWM in the context of national policy and legal framework, Institutional arrangement, appropriate technology, Operational and financial management, and public awareness and participation. In keeping with this approach, a generic action plan has been proposed that could be tailored to suit a situation in a particular country. This proposed concept and action plan frame work would be useful across a variety of country specific scenarios.

C. R. Lohari et.al, (2013): In this paper author studied cost-revenue analysis based on data from July 2009 to June 2011. The analysis show that the overall cost in bahir dars swm system increased significantly 
during this period mainly due to transportation of waste. On the other hand, there is only one major revenue stream in place: the collection fee from household, commercial enterprises and institutions. The author presented four option on how financial sustainability of the SWM system in bahir dar might enhanced: 1. Improved fee collection efficiency by linking the fees of solid waste collection to waste supply 2 . Increasing the value chain by sales of organic waste recycling products 3 . Diversifying revenue streams and financing mechanism 4. Cost reduction and improved cost-effectiveness.

A. Ahsan et.al (2014: The author represents few basic steps of municipal solid waste management practiced in the six major cities of Bangladesh, namely, Dhaka, Chittagong, Khulna, Rajshahi, barisa and Sylhet. A six-month field study was conducted to identify the solid wastes management steps such as storage at source, separation, on-site storage, collection, transportation, treatment, reuse, recycling and ultimate disposal. This study addresses the role of the city authority to meet the demand of the city dwellers in solving this emerging community-based organizations. The problem and constraints of the solid wastes management system are also identified to find a sustainable management concept for the urban areas of Bangladesh.

C. Zhang et.al (2014): The author studies the characteristics of FW, the principles of AD, the process parameters, and two approaches (pretreatment and co-digestion) for enhancing $\mathrm{AD}$ of food waste. Among the successive digestion reactions, hydrolysis is considered to be the rate-limiting step. To enhance the performance of $\mathrm{AD}$, several physical, thermochemicals, biological or combined pretreatments are reviewed. Moreover, a promising way for improving the performance of $\mathrm{AD}$ is the co-digestion of FW with other organic substrates, as confirmed by numerous studies, where a higher buffer capacity and an optimum nutrient balance enhance the biogas/methane yields of the co-digestion system.

T. Ghatak et.al (2016): In this paper, author generates certain issues related to waste management which have been experienced while being involved in various cities in national and international arena and picks up certain un addressed issues related to waste management in Indian cities. The main aim of this paper is to combine the opinion with learned group of participants and try to evolve an effective pathway for its management. One of the most prominent factors which is missing in the entire process is the role of community as a stake holder and their inclusion in the entire process. The author concluded that though the MSW rules 2000 have been in implementation for last 15 years in India, there are many unaddressed issues which need to be addressed with the effective implementation of the rules. In some cases, the rules need to be revisited.
Y. Ren et.al (2017):In this paper author presented an overview on the researches about anaerobic digestion of food waste. Technologies (e.g., pretreatment, codigestion, inhibition and mitigation, anaerobic digestion systems, etc.) were introduced and evaluated on the basis of bibliometric analysis. Results indicated that ethanol and aerobic prefer mentation were novel approaches to enhance substrates hydrolysis and methane yield. With the promotion of resource recovery, more attention should be paid to biorefinery technologies which can produce more useful products toward zero emissions. Furthermore, a technological route for food waste conversion based on anaerobic digestion was proposed. Based on the results the author concluded that Compared with the single-stage system, two-stage anaerobic system combined hydrogen or ethanol with methane fermentation could improve the energy recovery efficiency of the substrate and was considered a promising technology. In addition, the biorefinery would improve the commercial value of the anaerobic digestion of food waste due to the separated treatment on the basis of the component of the substrate.

\section{Objectives}

1) To determine Future population based on present census.

2) To determine generation of waste in next 30 years \& design biomethane plant for that design period.

3) To produce bio-gas which can be used for cooking \& electricity generation.

4) To utilize solid residue as manure and minimize environmental impact.

\section{Methodology}

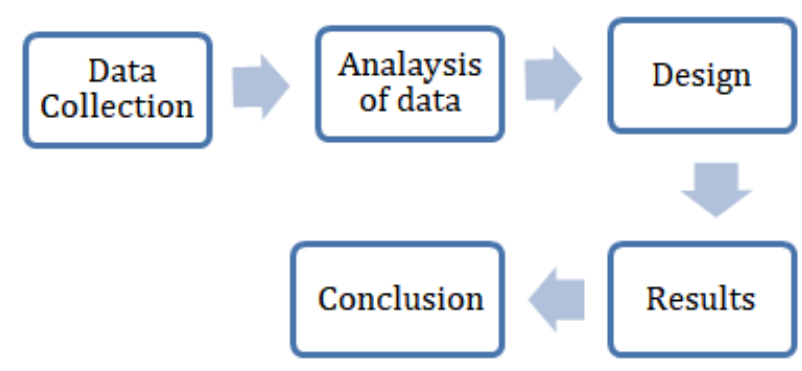

\subsection{Data Collection}

\subsubsection{Waste generation}

Essential data for the study, such as waste amount, population, current waste management techniques have been collected from site visits, net searching and SMKC official website. As per proforma of SMKMC there are two dumping sites being available for waste storage and treatment. One is $6 \mathrm{~km}$ away from Sangli, the total and acquired by SMKMC for waste dumping and treatment is 32 acres which is surrounded by boundary wall. The other site is situated on Miraj township and acquired land is 55 acres, this site is also 
well developed in terms of approach road, other facility like boundary wall, water facility etc. Since the waste produced by Sangli is about 210 MT/day. The following tables give details of solid waste generated in SMKMC.

Table-2 SMKMC MSW Generation Rate

\begin{tabular}{cc}
\hline $\begin{array}{c}\text { Generation rate of Municipal Solid } \\
\text { Waste in Sangli City }\end{array}$ & Qty \\
\hline $\begin{array}{c}\text { Total MSW generation (MT/day) } \\
\text { MSW generation (gm/capita/day) Of the } \\
\text { total MSW generated }\end{array}$ & $210 \mathrm{MT}$ \\
Domestic MSW (MT / day) & 120 \\
Commercial MSW (MT / day) \\
Waste from markets (MT/day) & 60 \\
Waste from hotels and restaurants (MT / \\
day)
\end{tabular}

\subsubsection{City population}

In 2011, Sangli had population of 2,822,143 of which male and female were 1,435,728 and 1,386,415 respectively. In 2001 census, Sangli had a population of $2,583,524$ of which males were 1,320,088 and remaining 1,263,436 were females. Sangli District population constituted $2.51 \%$ of total Maharashtra population. In 2001 census, this figure for Sangli District was at $2.67 \%$ of Maharashtra population.

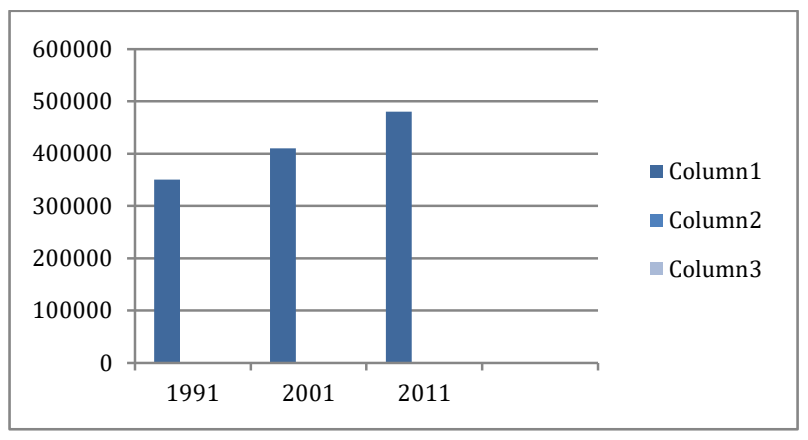

Fig-3 Population growth chart

\subsection{Analysis of Collected data}

\subsubsection{Population Forecasting of Sangli city}

In order to determine the present and future population of the city, we are using arithmetic increase and geometrical increase method, and compare the results obtained by both methods and will choose the most suitable results for further design.

Table-3 Population forecasting by Arithmetic increase method

\begin{tabular}{ccc}
\hline Year & Population & Increment \\
\hline 1991 & $1,93,197$ & - \\
2001 & $4,36,781$ & $2,43,584$ \\
2011 & $5,02,697$ & 65,916 \\
2016 & $5,80,072$ & 77,375 \\
\multicolumn{3}{c}{ Up to $2046=9,66,946$} \\
\hline
\end{tabular}

Table-4 Population forecasting by Geometric increase method

\begin{tabular}{cccc}
\hline Year & Population & Increment & $\begin{array}{c}\text { Geometrical } \\
\text { increase rate of } \\
\text { growth }\end{array}$ \\
\hline 1991 & $1,93,197$ & - & - \\
2001 & $4,36,781$ & $2,43,584$ & 1.26 \\
2011 & $5,02,697$ & 65,916 & 0.15 \\
2016 & $5,80,072$ & 77,375 & 0.15 \\
\hline \multicolumn{4}{c}{ Up to 2046 } \\
\hline
\end{tabular}

4.2.3 Generation of Waste in next 30 year in Sangli city

- 210 Metric ton waste / day

- 1 person generate $=250 \mathrm{gm} /$ day $/$ capita

- Out of 80 Metric ton waste is Biodegradable

- 15 to $20 \%$ waste increases per year.

- Waste generated after 30 year $=435$ Ton $/$ day

\section{Design of Bio-Methane plant}

Total quantity of biodegradable waste generated /day is $100 \mathrm{MT}$ out of which,

Garden, park, hotel, restaurant waste $=5 \mathrm{MT}$

Quantity of waste from market $=25$ MT

Slaughter house $=3 \mathrm{MT}$

Domestic waste $=67 \mathrm{MT}$

A) Design of Digester:

\section{Step- 1}

- Assume average yield of gas/Kg of mixed bio waste $=50$ lit $/ \mathrm{kg}$

- Qty of gas produced from above qty of waste = $100 \times 1000 \times 50=50,00000$ lit/day i.e 50,00000/ $1000=5000 \mathrm{cum} /$ day gas generated

- Assume 10 nos of plant each plant capacity 100000 $/ 10=10,000 \mathrm{Kg}$

Design made for one plant which similar to all plant.

\section{Step -2}

- Vol. of daily charge $=(\mathrm{Wt}$. of waste + Equal Wt. of water $)=(10,000+10,000)=20,000 \mathrm{~kg} /$ plant Taking density of slurry $=1090 \mathrm{~kg} / \mathrm{cum}$

- $\quad$ As per climate data of sangli city we consider HRT $=40$ days

- $\quad$ Digester vol. $=$ Vol. of daily charge $\times \mathrm{H} \mathrm{R} \mathrm{T}=$ $(2000 / 1090 \times 40)$

\section{$\mathrm{Vd}=733.94$ say $\underline{\mathbf{7 4 0} \text { cum }}$}

We choose circular shape digester

$$
\begin{aligned}
& \mathrm{Vd}=\frac{\pi}{4} \times D^{2} \times \mathrm{H} \\
& =\frac{\pi}{4} \times 18^{2} \times \mathrm{H}
\end{aligned}
$$


Assume dia $=18 \mathrm{~m}$

$\mathrm{H}=2.90 \mathrm{~m}$ Say $3.0 \mathrm{~m}$

Size of digester $=18 \mathrm{~m}$ dia and $3.0 \mathrm{~m}$ height.

B) Design of Balancing tank or Gasholder

Quantity of gas generated from gas generated from 1 plant

$=10,000 \times 50$

$=50,000$ lit

Vol. of balancing tank / gasholder $(\mathrm{Vg})=500 \mathrm{cum}$

$\operatorname{Vg}=\frac{\pi}{4} \times D^{2} \times \mathrm{H}$

$\mathrm{D}=\sqrt{500 \times 4 / \pi \times 2.15}$

$\mathrm{D}=17.20=18 \mathrm{~m}$

Size of gas holder = Día $18 \mathrm{~m}$ and Height $2.15 \mathrm{~m}$

C) Design of Mixing tank

Quantity of waste mix in mixing tank $=10,000 \mathrm{~kg} /$ day with equal quantity of water of 10,000 lit to make slurry.

i.e total quantity of slurry $=20,000$ lit $/$ day

Vol. of mixing tank is ( Vf) $=\frac{1}{2} \times 20,000$

Vf $=10,000$ lit i: e Vf = 10 Cum

Assume rectangular Square type mixing tank of dimension $3.0 \times 3.0 \mathrm{~m}$

Height of mixing tank $=\frac{10}{3 \times 3}$

$\mathrm{H}=1.11$ say $1.50 \mathrm{~m}$

Size of Mixing tank $=3.0 \times 3.0 \times 1.50 \mathrm{~m}$

D) Design of storage tank or Overflow tank: -

Vol. of storage tank $(V s)=\frac{1}{3} \times$ vol. of digester.

$=\frac{1}{3} \times 740$

(Vs) $=245$ Cum

Height of storage tank $=\frac{245}{10 \times 10}$

$\mathrm{H}=2.45 \mathrm{~m}$

Size of storage tank $=10 \times 10 \times 2.45 \mathrm{~m}$

E) Design of Manure Pit
Vol of manure pit $(\mathrm{Vp})=\frac{1}{2} \times$ Vol of storage tank

$=\frac{1}{2} \times 245$

$=122.5$ Cum

Assume 2 nos of rectangular type manure tank. Each of size $8 \times 5 \mathrm{~m}$

Height of manure tank $=\frac{61.25}{8 \times 5}=1.50 \mathrm{~m}$

Size of manure tank $=8.0 \times 5.0 \times 1.50 \mathrm{~m}$

\section{Results}

Table-5 Quantity of gas, Rate \& Profit

\begin{tabular}{cc}
\hline Total gas generated from 10 plant & $\mathbf{5 , 0 0 , 0 0 0 ~ l i t . ~}$ \\
\hline Rate of Gas & $20 \mathrm{Rs} / \mathrm{Lit}$. \\
\hline Total Money earn after Selling & $1,00,00,000 \mathrm{Rs} /-$ \\
\hline $\begin{array}{c}\text { Quantity of Manure after disposal } \\
\text { Manure Selling Price }\end{array}$ & $196 \mathrm{Cum}$ \\
\hline $\begin{array}{c}\text { Total Money earn after Manure Sell } \\
\text { Total profit after disposal of MSW } \\
\text { from all plant }\end{array}$ & $89,700 \mathrm{Rs} /-$. \\
\hline
\end{tabular}
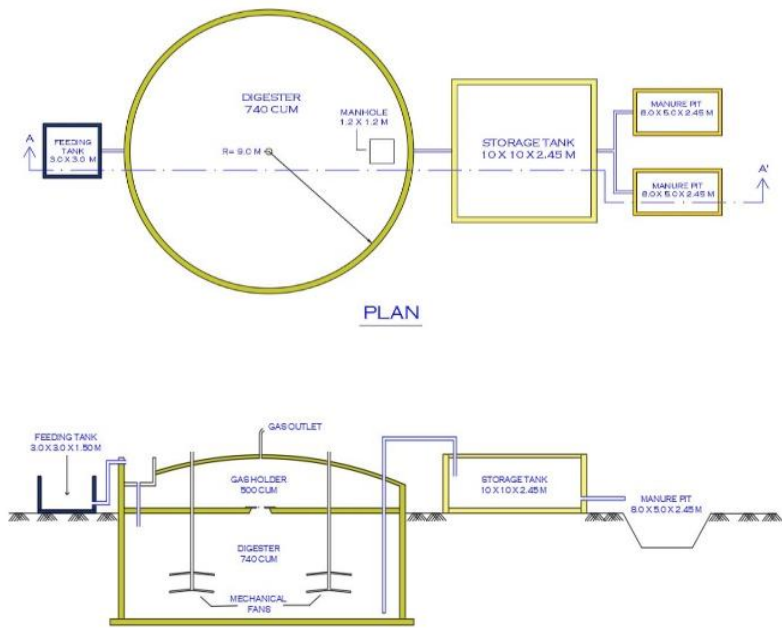

SECTION A-A

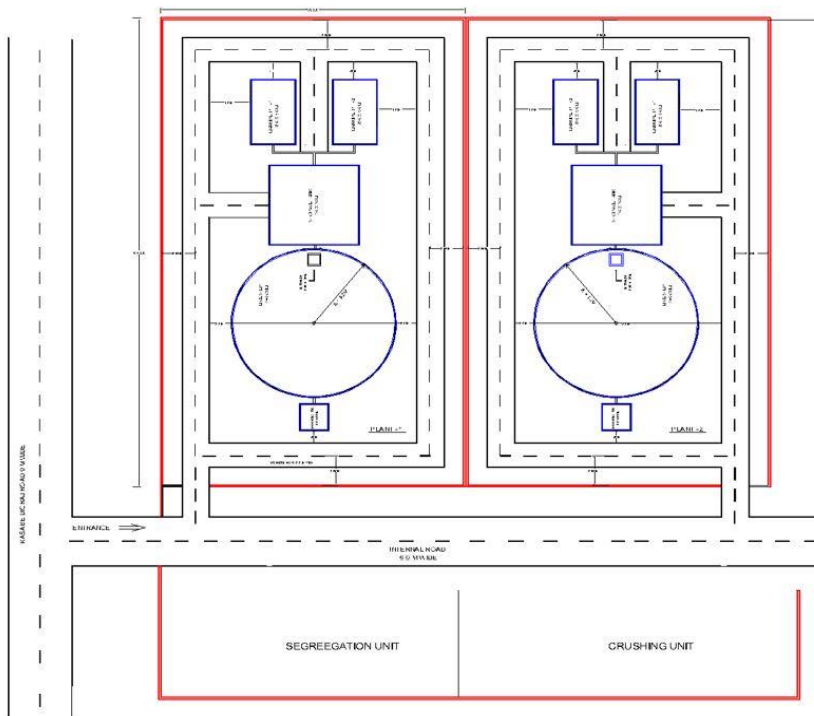




\section{Conclusion}

The Biomethane Plant designed for Sangli city is the best suited. based upon the result of this paper it is very clear that Bio-methanation after segregation is the best possible option to address solid waste in city. The Anaerobic composting is very economical method of treatment the solid waste in any city. The main advantage of this method is that it is the best solution for 'Global warming' which is major problem faced by the world today. After the implementation of the project the conditions will improve in following respect;

1) Improving solid waste management practices so as to reduce environmental pollution and improve the quality of life in the city.

2) Segregation of waste into specified types.

3) Maximum recycling of waste.

4) Maximum local composting of bio-degradable waste.

5) Saving in transportation cost of waste.

6) Minimizing the quantity of waste received at the land fill.

7) Easy to implement and operate as compared to the other advanced treatment methods.

8) Area required is less as compared to present condition.

\section{References}

M. Stenstrom (1983), Anaerobic digestion of Municipal solid waste, Journal of Environmental Engineering, Vol.109, PP.1148-1158.

T. Narayana (2008), Municipal solid waste management in India: From waste disposal to recovery of resources, Elsevier Waste Management, Vol.29, PP.1163-1166.

A. Shekdar (2009), Sustainable solid waste management: An integrated approach for Asian countries, Elsevier Waste Management, Vol.29, PP.1438-1448.

C. R. Lohri (2013), Financial sustainability in municipal solid waste management- Costs \& revenues in Bahir Dar Ethiopia, Elsevier Waste Management, Vol.34, PP.542-552.

A. Ahsan (2014), Assessment of municipal solid waste management system in a developing country, Hindawi Publishing Corporation Chinese Journal of Engineering Vol.1, PP.1-11.

C. Zhang (2014), Reviewing the anaerobic digestion of food waste for biogas production, Elsevier Renewable \& Sustainable Energy Review, Vol.38, PP.383-392.

T. Ghatak (2016), Municipal solid waste management in India: A few unaddressed issues, Elsevier Procedia Environmental Science, Vol. No-35.169-175.

Y. Ren (2017), A comprehensive review on food waste anaerobic digestion: Research updates \& tendencies, Elsevier Bioresource Technology, Vol.247, PP.1069-1076. 